\title{
Differential Modulation of Synaptic Transmission by Calcium Chelators in Young and Aged Hippocampal CA1 Neurons: Evidence for Altered Calcium Homeostasis in Aging
}

\author{
Aviv Ouanounou, ${ }^{1,2,3,4}$ Liang Zhang, ${ }^{1,3}$ Milton P. Charlton, ${ }^{1,2,4}$ and Peter L. Carlen ${ }^{1,2,3,4}$ \\ ${ }^{1}$ Playfair Neuroscience Unit, Toronto Hospital Research Institute, ${ }^{2}$ Medical Research Council Group on Nerve Cells \\ and Synapses, and Departments of ${ }^{3}$ Medicine (Neurology) and 4 Physiology, University of Toronto, Toronto, \\ Ontario M5T 2S8, Canada
}

The effects of membrane-permeant $\mathrm{Ca}^{2+}$ chelators on field EPSPs (fEPSPs) were measured in the hippocampal CA1 region of brain slices from young (2-4 months) and old (24-27 months) Fischer 344 rats. BAPTA-AM depressed fEPSPs in young slices by up to $70 \%$ but enhanced fEPSPs by $30 \%$ in aged slices. EGTA-AM, with slower binding kinetics, did not affect fEPSPs from young slices but enhanced fEPSPs in aged slices. BAPTA derivatives with calcium dissociation constants $\left(K_{d}\right)$ of $0.2-3.5$ $\mu \mathrm{M}$ reduced or enhanced fEPSPs in young and aged slices, respectively, but $5^{\prime}, 5^{\prime}$-dinitro BAPTA-AM $\left(K_{d}\right.$ of $\left.\sim 7000 \mu \mathrm{M}\right)$ had no effect. Frequency facilitation of the fEPSPs occurred in young, but not in aged, slices, except when BAPTA-AM or
EGTA-AM was perfused onto aged slices. The differential effects of BAPTA-AM in young and old slices were eliminated by perfusing with a low $\mathrm{Ca}^{2+}$-high $\mathrm{Mg}^{2+}$ saline or with the calcium blocker $\mathrm{Co}^{2+}$. These data suggest that intracellular $\mathrm{Ca}^{2+}$ regulation is altered and raised in aged neurons. Cell-permeant calcium buffers may be able to "ameliorate" deficits in synaptic transmission in the aged brain.

Key words: calcium chelator; BAPTA-AM; EGTA-AM; probenecid; hippocampus; field EPSP; frequency facilitation; synaptic transmission; aging
Calcium ions are involved in numerous neuronal signaling processes, such as the control of presynaptic neurotransmitter release (Augustine et al., 1985, 1991), the regulation of membrane excitability (Ghosh and Greenberg, 1995), long-term potentiation (Bliss and Collingridge, 1993; Nicoll and Malenka, 1995), and as a second messenger (for review, see Augustine et al., 1985; Blaustein, 1988; Simpson et al., 1995). Several lines of evidence point to alteration in $\mathrm{Ca}^{2+}$ regulation in brains of aging rodents (Landfield and Pitler, 1984; Gibson and Peterson, 1987; Verkhratsky and Toescu, 1998). In neurons from aged rat brain, altered $\mathrm{Ca}^{2+}$ extrusion, buffering, and uptake (Michaelis et al., 1984; Iacopino and Christakos, 1990; Martinez-Serrano et al., 1992) and reduced clearance of $\mathrm{Ca}^{2+}$ from aged nerve terminals (Martinez et al., 1987; Smith, 1988) have been measured. L-type $\mathrm{Ca}^{2+}$ channels (Thibault and Landfield, 1996) and currents (Campbell et al., 1996) are increased in aged CA1 neurons. The above observations support the "calcium hypothesis" of aging, which implicates raised intracellular $\mathrm{Ca}^{2+}$ as the major cause of functional impairment and degeneration in aged neurons (Khachaturian, 1989, 1994; Verkhratsky and Toescu, 1998).

Recently, it was demonstrated by several groups (Scharfman and Schwartzkroin, 1989; Kudo et al., 1990; Tymianski et al.,

Received July 27, 1998; revised Oct. 28, 1998; accepted Nov. 18, 1998.

This work was supported by grants from the Medical Research Council (to P.L.C.), the Network on Neuronal Recovery, and Regeneration of the Networks of Centres of Excellence of Canada (to P.L.C. and M.P.C.). L.Z. is a Research Scholar of the Heart and Stroke Foundation of Canada and Ontario. We thank Frank Vidic for his assistance with electronics and computerized data processing and Drs. Michael Tymianski, Hossam El-Beheiry, Giovanni Facciponte, and Patrick McDonald for helpful discussions throughout this study.

Correspondence should be addressed to Dr. Peter L. Carlen, Room 12-413, Playfair Neuroscience Unit, Toronto Hospital-Western Division, 399 Bathurst Street, Toronto, Ontario M5T 2S8, Canada.

Copyright (C) 1999 Society for Neuroscience $0270-6474 / 99 / 190906-10 \$ 05.00 / 0$
1993, 1994a) that membrane-permeant calcium chelators may protect neurons in an in vitro model of glutamate-induced cell death (for review, see Choi, 1988, 1995) and in a rat stroke model in vivo (Tymianski et al., 1993, 1994b). These studies show that calcium buffers with fast binding kinetics and higher binding affinities (e.g., BAPTA-AM) were the most neuroprotective. The AM moiety permits cell membrane permeation, and it is then cleaved by intracellular esterases to form the active chelating calcium buffer (Tsien, 1980). We have examined the effects of concentration, $\mathrm{Ca}^{2+}$ affinity, $\mathrm{Ca}^{2+}$ binding rate, and extrusion of permeant $\mathrm{Ca}^{2+}$ chelator on synaptic field potentials of hippocampal CA1 neurons in brain slices from young (20-35 d) Wistar rats (Ouanounou et al., 1996b). The application of BAPTA-AM for $15 \mathrm{~min}$ attenuated the synaptic field potential amplitude. Probenecid, an anion transport inhibitor, accelerated and enhanced the depression of synaptic potentials by concentrations of BAPTA-AM as low as $0.05 \mu \mathrm{M}$ (Ouanounou et al., 1996b). We have also shown that calcium currents, which were depressed in aged dentate gyrus neurons, were enhanced by intracellularly applied EGTA (Reynolds and Carlen, 1989).

In light of these observations, we compared the effects of membrane-permeant calcium chelators on synaptic transmission in hippocampal slices taken from young-mature and aged Fischer 344 rats. We found that both BAPTA-AM and EGTA-AM enhanced the fEPSP in aged slices, suggesting that there is tonic elevation of $\left[\mathrm{Ca}^{2+}\right]_{i}$ in the aged neuron. These enhancing effects of calcium chelators could be completely reversed if $\mathrm{Ca}^{2+}$ influx was partially blocked by either reducing the extracellular $\mathrm{Ca}^{2+}$ / $\mathrm{Mg}^{2+}$ ratio or incubating the slices with $\mathrm{Co}^{2+}$.

Part of this work was published previously in abstract form (Ouanounou et al., 1996a). 


\section{Table 1. Maximal fEPSP and presynaptic volley amplitudes in young} and old rats

\begin{tabular}{lll} 
& $\begin{array}{l}\text { Maximal fEPSP amplitude } \\
(\mathrm{mV})\end{array}$ & $\begin{array}{l}\text { Presynaptic volley amplitude } \\
(\mathrm{mV})\end{array}$ \\
\hline Young & $1.8 \pm 0.09(n=12)$ & $0.3 \pm 0.02(n=12)$ \\
Old & $1.2 \pm 0.03^{*}(n=10)$ & $0.3 \pm 0.01(n=10)$
\end{tabular}

Values are mean \pm SE. As indicated, data are taken from 12 slices in young (4) rats and 10 slices in old (3) rats. ${ }^{*} p<0.01$; Student's paired $t$ test.

\section{MATERIALS AND METHODS}

Tissue preparation. Brain slices were obtained from young-adult (2-4 months) and aged (24-27 months) Fischer 344 rats. Rats were anesthetized with halothane (Halocarbon Laboratories, River Edge, NJ) and decapitated, and the brain was quickly removed, hemisected, and placed in ice-cold $\left(4^{\circ} \mathrm{C}\right)$ artificial CSF (ACSF) for $\sim 3 \mathrm{~min}$. Although the skulls of aged animals are somewhat thicker than those of young animals, the period required to remove the brain was not substantially longer, and we have not observed consistent differences in the viability of slices from aged and young animals. Brain slices were cut to $400 \mu \mathrm{m}$ thickness with a Vibratome (Series 1000; Technical Products, Inc., St. Louis, MO) and incubated in ACSF at room temperature for a minimum of $1 \mathrm{hr}$ before recording. ACSF contained (in $\mathrm{mM}$ ): $120 \mathrm{NaCl}, 2.5 \mathrm{KCl}, 2 \mathrm{CaCl}_{2}, 2$ $\mathrm{MgCl}_{2}, 25 \mathrm{NaHCO}$, and $10 \mathrm{D}$-glucose, $\mathrm{pH} 7.4$, continuously bubbled with $95 \% \mathrm{O}_{2}-5 \% \mathrm{CO}_{2}$.

Extracellular recordings. Slices were transferred to a submerged recording chamber and continuously perfused with bubbled ACSF at $35 \pm$ $0.5^{\circ} \mathrm{C}$. Recording pipettes were inserted into either the apical dendritic region of the Schaffer collateral-commissural termination in the stratum radiatum of the hippocampal CA1 field to record the field EPSPs (fEPSPs) or the stratum pyramidal of CA1 to record population spikes. A stimulating electrode (bipolar twisted wire) was placed on the Schaffer collateral-commissural fibers for orthodromic activation of CA1 neurons. Population spike amplitudes were measured from the onset of the spike to the negative peak. The amplitude of the fEPSP in the dendrites was measured from the baseline to the maximum negative deflection. Stable responses $( \pm 10 \%)$ for $10 \mathrm{~min}$ before drug application were required. Afferent fiber spike amplitude (the presynaptic volley) was measured in those dendritic records in which they were present. Signals were recorded by an Axoclamp 2A amplifier (Axon Instruments, Foster City, CA). Field potentials were evoked every $30 \mathrm{sec}$. Data were collected, digitized, and analyzed using pClamp software (version 5.1; Axon Instruments) on an IBM personal computer. Although the number of slices are noted, all statistical differences were assessed by the Student's paired $t$ test comparing the number of rats (also noted for each experiment) in each group. Unless otherwise stated, mean \pm SE were shown throughout the text. All drug responses were measured 40-45 min after onset of drug perfusion.

Drug preparation. BAPTA-AM was initially dissolved in DMSO and then diluted to its final concentration in the ACSF. DMSO concentration in ACSF was $0.1 \%$ for the highest concentration $(50 \mu \mathrm{M})$ of BAPTAAM. In addition, 2-hydroxypropyl- $\beta$-cyclodextran (0.7 mM; Research Biochemicals, Natick, MA) was used to stabilize the chelator in the aqueous ACSF, presumably protecting the AM moiety from hydrolysis. EGTA-AM, 5',5'-dinitro BAPTA-AM, 5'5'-difluoro BAPTA-AM, and 5'5'-dibromo BAPTA-AM (Molecular Probes, Eugene, OR) were dissolved initially in DMSO. Probenecid (Sigma, St. Louis, MO) was dissolved in $1 \mathrm{M} \mathrm{NaOH}$ and buffered to $\mathrm{pH} 7.4$ using $\mathrm{HCl}$ acid. When probenecid was used, sodium concentration in the ACSF was adjusted to be the same as in the normal ACSF.

\section{RESULTS}

\section{BAPTA-AM attenuates fEPSPs in young rats but enhances those in aged rats}

Extracellular recording from the stratum radiatum of the CA1 area shows a response that is usually composed of a presynaptic volley and an fEPSP. The fEPSP that follows the presynaptic volley reflects the extracellular sum of single EPSPs at the level of the Schaffer collaterals. As shown in Table 1, the maximal fEPSP amplitudes were significantly reduced with age, consistent with previous observations (Landfield et al., 1986; Deupree et al., 1993). As shown previously in the studies mentioned above, there were no significant differences in the presynaptic volleys between young and aged rats (Table 1). These results are consistent with a reduction in the number of functional synaptic contacts made by individual Schaffer collateral axons onto old CA1 cells (Barnes et al., 1992; Barnes, 1994) or could also be caused by alterations in the postsynaptic effectiveness of released transmitter.

Recently, we showed that BAPTA-AM attenuated synaptic field potentials recorded from the stratum radiatum in a concentration-dependent manner in young (20-35 d) Wistar rats (Ouanounou et al., 1996b). BAPTA-AM was more efficient when applied together with probenecid $(1 \mathrm{mM})$, an anion transport blocker, which presumably blocks the extrusion of BAPTA from the presynaptic terminal. Following the same strategy, BAPTA-AM $(1 \mu \mathrm{M})$ was applied in the presence of $1 \mathrm{~mm}$ probenecid after a stable baseline was achieved. To control for the possible effects of DMSO, cyclodextran, and probenecid (see Materials and Methods), the slices were perfused with ACSF containing the same concentrations of the above agents until a stable baseline was achieved before the application of BAPTAAM. BAPTA-AM application for 20-25 min attenuated the fEPSPs in young slices by $58 \pm 4 \%$ ( $n=5$ slices from 5 rats); however, it enhanced the fEPSP in aged slices by $31 \pm 6 \%(n=$ 9 slices from 6 rats) (Fig. 1). The maximal effect was achieved within 10-12 min from the application time. fEPSP attenuation (or enhancement) by BAPTA was reversible on washout once probenecid had been removed and was reproduced by a second BAPTA application (young, $n=4$ slices from 4 rats; aged, $n=6$ slices from 4 rats; data not shown).

When the Schaffer collateral pathway was stimulated, there was a population spike amplitude of $\sim 2 \mathrm{mV}$ in the stratum pyramidal (somatic region), representing postsynaptic action potentials in response to the excitatory stimulus. Superfusion of the young brain slices with ACSF containing $1 \mu \mathrm{M}$ BAPTA-AM and $1 \mathrm{~mm}$ probenecid for $20 \mathrm{~min}$ attenuated the population spike amplitude by $68 \pm 8 \%(p<0.01$; Student's $t$ test $)$ when measurements were taken 20 min after the onset of the BAPTA application. However, when aged slices were perfused with the same concentration of BAPTA-AM, the population spike amplitude was enhanced by $28 \pm 3 \%$ ( $n=4$ slices from 3 rats).

To determine whether the action of BAPTA might be attributed to altered inhibitory synaptic transmission, the experiments in both the young-adult and aged slices were repeated using ACSF containing the $\mathrm{GABA}_{\mathrm{A}}$ blocker bicuculline $(10 \mu \mathrm{M})$. Results similar to those shown in Figure 1 were obtained (young, $52 \pm 4 \%$ depression; $n=5$ slices from 4 rats; aged, $27 \pm 5 \%$ enhancement; $n=6$ slices from 5 rats), supporting the notion that BAPTA-AM directly attenuates excitatory responses in young animals and enhances those in aged. In the present study, the attenuation (or enhancement) of the fEPSPs occurred without clearly affecting the presynaptic volley amplitude (Fig. 1, arrows; see also Fig. 4, arrows), suggesting that BAPTA is unlikely to act on axonal spike invasion into the presynaptic terminal.

We next asked whether the enhancing effects that we observed in the aged neurons were attributable to failure to accumulate sufficient BAPTA intracellularly. For instance, Robitaille and Charlton (1992) and Robitaille et al. (1993a) found that for a short time, when its intracellular concentrations would be small, BAPTA-AM actually enhanced transmitter release at the frog neuromuscular junction, but later, when intracellular BAPTA concentration should have increased, transmitter release was in- 


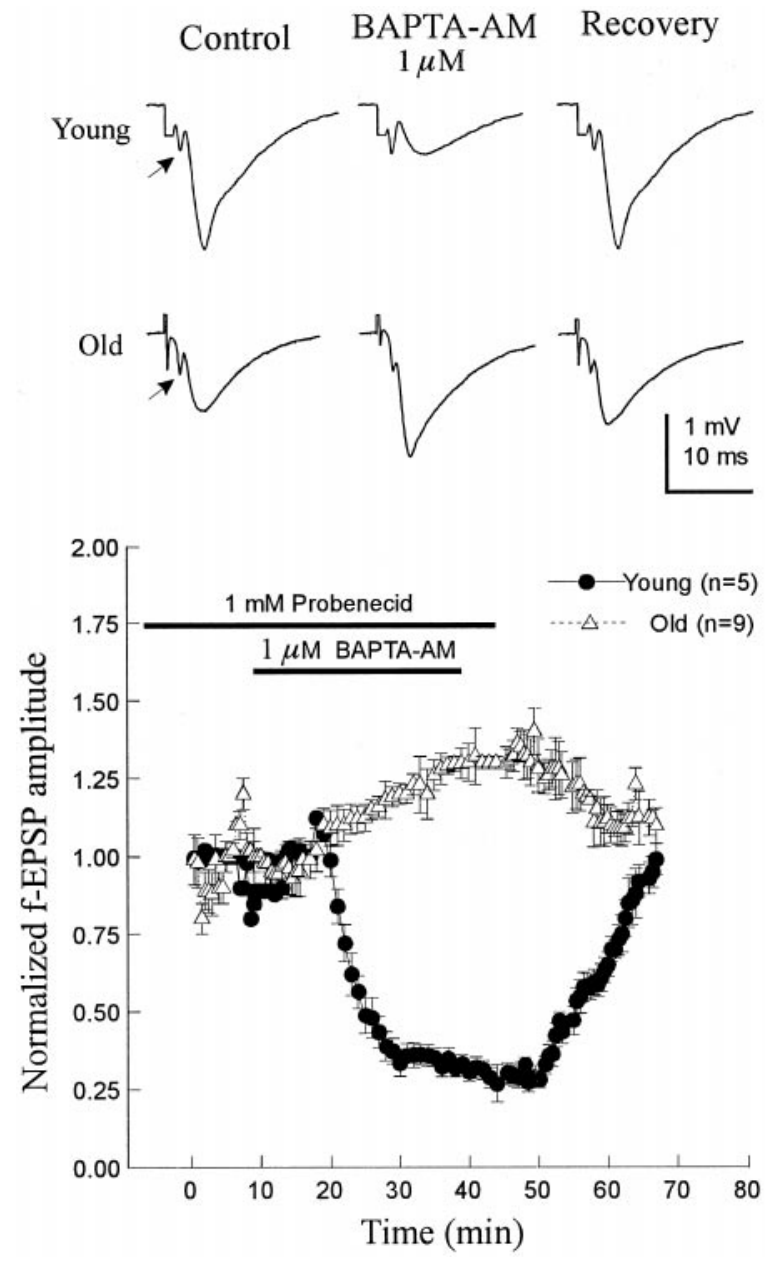

Figure 1. BAPTA-AM attenuates the fEPSPs in young slices but enhances fEPSPs in aged slices. Top, Sample tracing recording of fEPSPs during control condition, during BAPTA-AM and probenecid application, and after removal of the drugs. Bottom, Normalized fEPSP $( \pm \mathrm{SE})$ plotted against time. Slices (5 young from 5 rats; 9 old from 6 rats) were incubated in ACSF with probenecid (see Materials and Methods), and, after a stable baseline was achieved, BAPTA-AM was applied. fEPSPs were reduced in the young and enhanced in the aged slices without a clear effect on the presynaptic volley (arrows).

hibited. They showed that this enhancement was caused by block of $\mathrm{Ca}^{2+}$-gated $\mathrm{K}^{+}$channels in the presynaptic terminal. If enhancement in aged slices is attributable to the inability to accumulate BAPTA sufficiently, then increasing the BAPTA-AM concentration would cause a more rapid increase in intracellular BAPTA and attenuate the fEPSP, even in the aged slices. However, BAPTA-AM application to the young slices at a concentration of 1,10 , or $50 \mu \mathrm{M}$ caused fEPSP depressions of $52 \pm 7(1 \mu \mathrm{M}$; $n=6$ slices from 4 rats $), 66 \pm 5(10 \mu \mathrm{M} ; n=4$ slices from 4 rats $)$, and $71 \pm 11 \%(50 \mu \mathrm{M} ; n=9$ slices from 6 rats) (Fig. 2) when measured 40 min after the onset of the BAPTA-AM application. These results show that increasing concentrations of BAPTA-AM can have larger effects in young, but not old, slices, confirming our previous observations in brain slices from young Wistar rats (Ouanounou et al., 1996b). Application of 1 ( $n=9$ slices from 6 rats), 10 ( $n=5$ slices from 3 rats $)$, or $50 \mu \mathrm{M}(n=8$ slices from 5 rats) BAPTA-AM with $1 \mathrm{~mm}$ probenecid for $40 \mathrm{~min}$ enhanced the fEPSP by $\sim 30 \%$ (Fig. 2). At these concentrations, it is unlikely that BAPTA-AM entry was inhibited or was not active, particu-

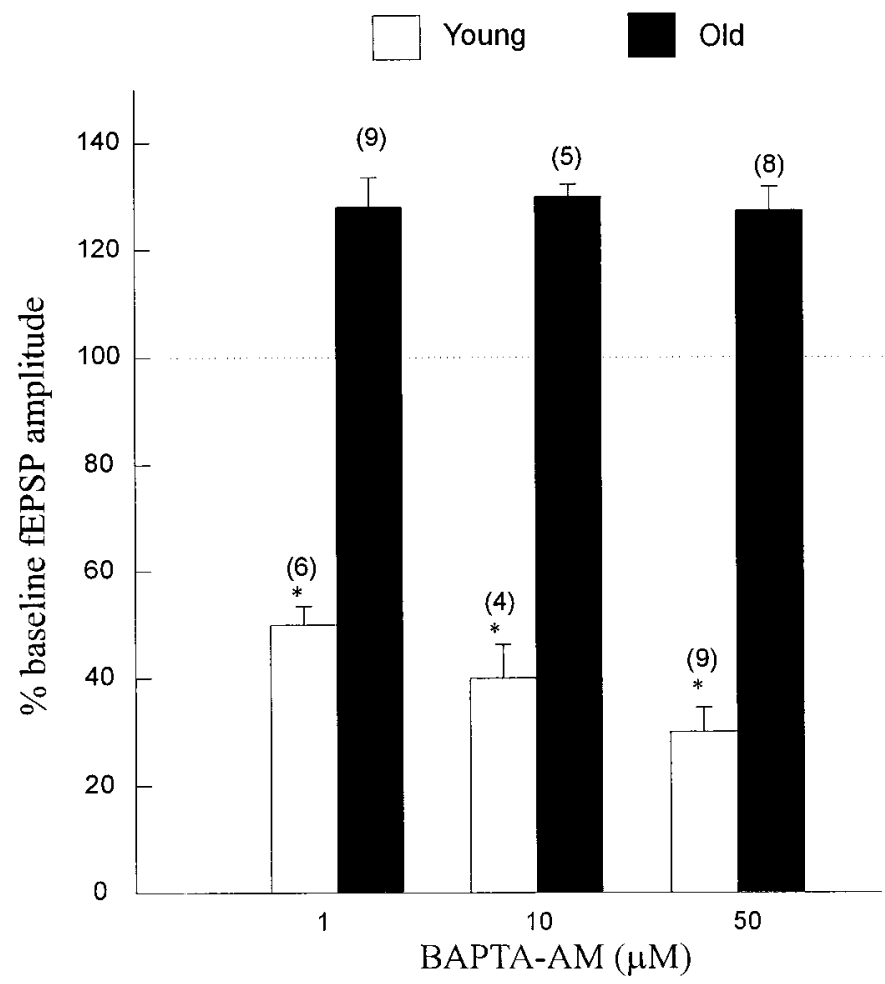

Figure 2. Effects of different concentrations of BAPTA-AM on the fEPSP amplitude in young and aged Fischer 344 rats. Slices were perfused for 15-20 min with ACSF until stable recordings (changes in the baseline fEPSPs of $< \pm 10 \%$ for 10 min before drug application) were achieved. In the young animals (open bars), the application of 1,10 , or $50 \mu \mathrm{M}$ and $1 \mathrm{mM}$ probenecid for 40 min caused a reduction in the fEPSP amplitude, but in the aged (filled bars), BAPTA-AM caused enhancement of the fEPSP. Numbers in parentheses are the number of brain slices used to generate the average plotted values (mean $\pm \mathrm{SE}$ ). ${ }^{*} p<0.001$; paired Student's $t$ test.

larly because $1 \mathrm{~mm}$ probenecid was added to the ACSF (Ouanounou et al., 1996b). Furthermore, aged slices perfused with $50 \mu \mathrm{M}$ BAPTA-AM for $1 \mathrm{hr}$ showed enhancement of the fEPSP amplitude ( $n=6$ slices from 5 rats; $25 \pm 3 \%$ enhancement).

\section{BAPTA-AM effects in young and aged slices occurred at all stimulus intensities}

We questioned whether the excitatory synapses would be affected by BAPTA-AM at all stimulation intensities, i.e., lower intensities may show different effects than higher intensities during application of BAPTA-AM to the slices. To test this hypothesis, the effect of $50 \mu \mathrm{M}$ BAPTA-AM and $1 \mathrm{~mm}$ probenecid at different stimulation intensities was examined in young and aged slices. The stimulus strength was altered to determine the range of synaptic responses when different numbers of presynaptic axons were stimulated. Responses to different stimuli between threshold and maximum were obtained to construct an input-output (I-O) curve from averaged potentials ( $n=4$ at each stimulus). After generation of the baseline I-O curve, BAPTA-AM and probenecid were applied. The BAPTA effect, i.e., reduction or enhancement of the field amplitude in young and aged slices, respectively, was observed at all stimulation intensities (Fig. 3), suggesting that this phenomenon is not dependent on a particular stimulation intensity and is therefore not peculiar to a small number of synapses. 

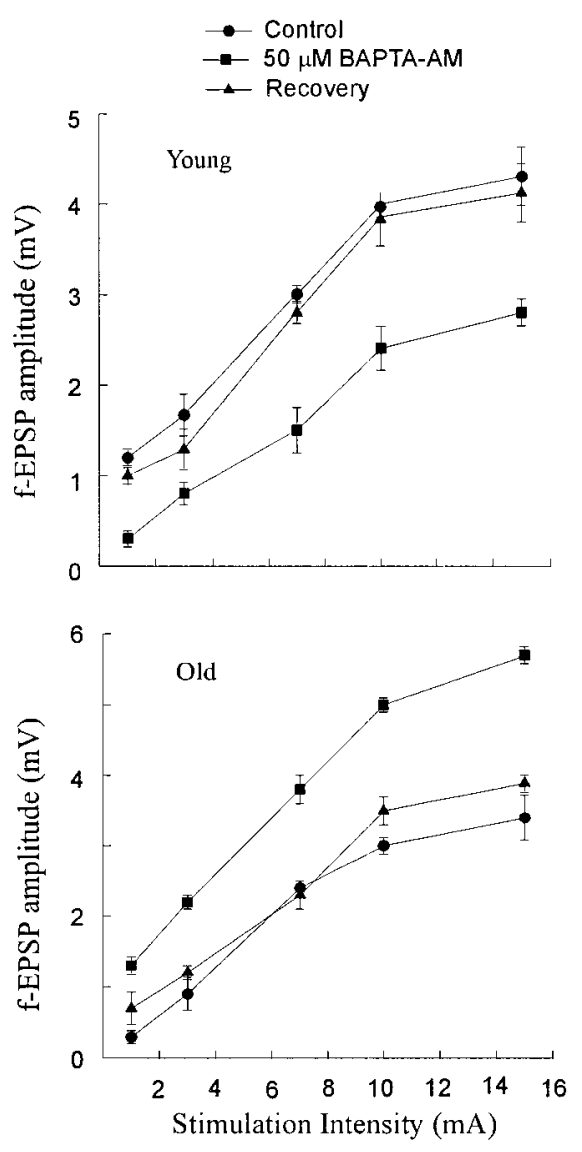

Figure 3. BAPTA-AM reduced or enhanced the fEPSP amplitude in young and aged slices, respectively, at all stimulation intensities. I-O curves for fEPSP amplitude versus the stimulation intensity. Data were generated by averaging the fEPSP amplitudes at the different stimulation intensities in six slices from four young rats and in 10 slices from five aged rats. BAPTA effects were significantly different $(p<0.05)$ from control and recovery (30 min after drug washout) conditions at each stimulus intensity.

\section{EGTA-AM enhances the fEPSP in aged slices}

The importance of the $\mathrm{Ca}^{2+}$ binding rate on the ability of the chelator to block synaptic transmission in young animals and to enhance that in aged was examined next. BAPTA binds $\mathrm{Ca}^{2+}$ ions $\sim 100$ times faster than EGTA, although both have similar $\mathrm{Ca}^{2+}$ affinities (Smith et al., 1984; Kao and Tsien, 1988; Pethig et al., 1989; Augustine et al., 1991). In contrast to BAPTA-AM, the application of $50 \mu \mathrm{M}$ EGTA-AM with $1 \mathrm{mM}$ probenecid $(n=5$ slices from 4 rats) (Fig. 4) caused no significant change in the fEPSP amplitude as measured 45 min after EGTA-AM bath application to the young slices. The lack of effect of EGTA-AM, the slow $\mathrm{Ca}^{2+}$ chelator, is unlikely to be caused by poor loading of this compound given the concentration used. The probable explanation remains that the kinetics of calcium binding by EGTA are too slow relative to $\left[\mathrm{Ca}^{2+}\right]_{i}$ stimulation of evoked transmitter release (Adler et al., 1991; Augustine et al., 1991).

If aging is associated with tonically elevated intracellular calcium concentration, application of EGTA-AM, as well as BAPTA-AM, might also enhance the fEPSP in the aged slices, regardless of the binding kinetics. When aged slices were incubated with $50 \mu \mathrm{M}$ EGTA-AM and $1 \mathrm{mM}$ probenecid, the fEPSP was enhanced by $36 \pm 5 \%$ ( $n=6$ slices from 4 rats) (Fig. 4$)$,
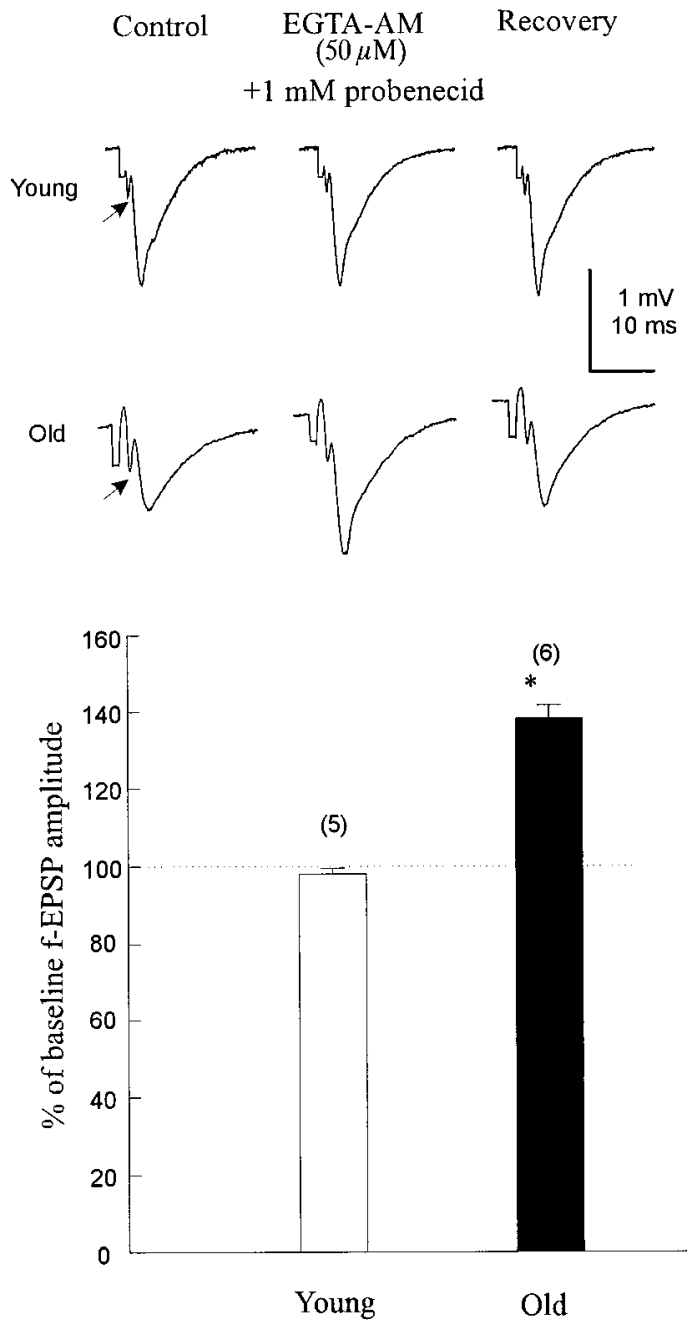

Figure 4. EGTA-AM $(50 \mu \mathrm{M}), \mathrm{a} \mathrm{Ca}^{2+}$ chelator with slow $\mathrm{Ca}^{2+}$-binding kinetics, enhanced the fEPSP amplitude in slices from aged animals but did not attenuate fEPSPs when applied to young-mature brain slices for 45 min. Top, Single recordings from young and aged slices during control, EGTA-AM application, and washout. Bottom, Bars indicate mean \pm SE. Numbers in parentheses represent the number of slices in each group. ${ }^{*} p<$ 0.01 , significant difference from baseline; paired Student's $t$ test. Note the significant effect that EGTA-AM had on the fEPSPs, but not on the presynaptic volleys, in aged slices (arrows).

suggesting that fast association and dissociation binding kinetics are not required for this effect in aged animals.

\section{Effect of BAPTA derivatives with different calcium affinities}

We investigated the effects of several BAPTA derivatives with different calcium affinities, including 5',5'-difluoro BAPTA-AM $\left(0.7 \mu \mathrm{M}\right.$ estimated $\left.K_{\mathrm{d}}\right), 5^{\prime}, 5^{\prime}$-dibromo BAPTA-AM $(3.5 \mu \mathrm{M}$ estimated $\left.K_{\mathrm{d}}\right)$, and $5^{\prime}, 5^{\prime}$-dinitro BAPTA-AM, a low affinity BAPTA analog (7000 $\mu \mathrm{M}$ estimated $K_{\mathrm{d}}$ ) (Pethig et al., 1989). All compounds were applied at $1 \mu \mathrm{M}$ with $1 \mathrm{~mm}$ probenecid (Ouanounou et al., 1996b), and, except for 5',5'-dinitro BAPTA-AM, were capable of reducing the fEPSP amplitude in young slices and enhancing those in aged slices (Fig. 5). The mean reduction in transmission produced by $5^{\prime}, 5^{\prime}$-difluoro BAPTA-AM in the young slices was $43 \pm 3 \%$, and the mean enhancement in the aged slices was $26 \pm 2 \%$. As for $5^{\prime} 5^{\prime}$-dibromo BAPTA-AM, there was 


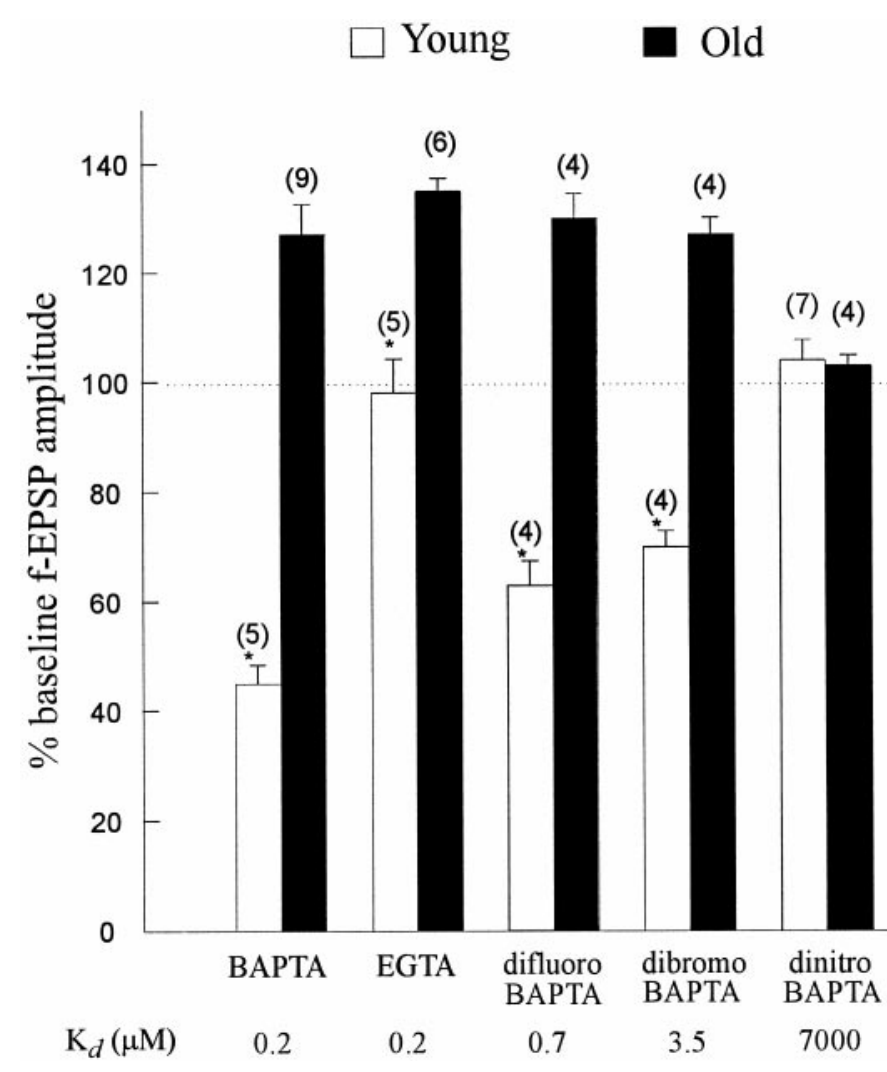

Figure 5. Relative ability of several BAPTA derivatives to reduce or enhance synaptic transmission in young and aged slices, respectively. Values are mean \pm SE. ${ }^{*} p<0.01$; paired Student's $t$ test. Numbers in parentheses indicate the number of slices used. $K_{d}$, Estimated dissociation constant. The numbers of animals for each condition are as follows (young and old, respectively): BAPTA, four and five; EGTA, four and five; difluoro BAPTA, four and three; dibromo BAPTA, four and three; and dinitro BAPTA, six and four.

a $38 \pm 2 \%$ depression in fEPSP amplitude in young slices and a $23 \pm 3 \%$ enhancement in the aged slices.

The effects seen were attributable to the BAPTA analogs rather than to the hydrolyzed AM ester moiety, because treating the slices with $50 \mu \mathrm{M} 5^{\prime}, 5^{\prime}$-dinitro BAPTA-AM, a permeant BAPTA analog with a low affinity $\left(K_{\mathrm{d}}\right.$ values in the micromolar range) (Pethig et al., 1989) had no effect in young and aged slices (young, $n=7$ slices from 6 rats; aged, $n=4$ slices from 4 rats) (Fig. 5).

\section{BAPTA-AM and EGTA-AM permit frequency facilitation in aged neurons}

In some central systems, EPSP amplitude increases substantially during repetitive stimulation ("frequency facilitation"), as does the probability of spike generation. We examined the effects of a $1 \mathrm{~Hz}$ repetitive stimulation for $16 \mathrm{sec}$ in young and aged slices. In younger slices, the amplitude of the fEPSP tended to increase with increasing number of stimuli; after 16 stimuli, the fEPSP was increased by $44 \pm 4 \%$ ( $n=7$ slices from 4 rats; $p<0.01)$. In aged slices, only the first one to two stimuli caused an increase in the fEPSP, and after 16 stimuli, no significant frequency facilitation was noted ( $n=8$ slices from 5 rats).

We next tested the effect of repetitive stimulation ( $1 \mathrm{~Hz}$ for 16 sec) in the presence of BAPTA-AM. In seven slices examined, we observed an $83 \pm 3 \%$ increase in the fEPSP amplitude in the aged slice in the presence of BAPTA-AM (Fig. 6). Similar effects occurred in aged slices in the presence of EGTA-AM $(n=6$ slices from 6 rats; a $49 \pm 5 \%$ increase in the fEPSP amplitude).

\section{Restricted $\mathrm{Ca}^{2+}$ entry causes calcium chelators to depress $f E P S P$ in aged slices}

Although there may be a number of potential sites of altered $\mathrm{Ca}^{2+}$ homeostasis in aged neurons, several electrophysiological studies have pointed to a specific potential source of disregulated neuronal calcium, namely excessive $\mathrm{Ca}^{2+}$ influx (Landfield and Pitler, 1984; Campbell et al., 1996; Thibault and Landfield, 1996). To examine this hypothesis, we lowered the extracellular calcium concentration to $0.5 \mathrm{~mm}$ (from $2 \mathrm{~mm}$ ), and increased $\mathrm{Mg}^{2+}$ to 4 $\mathrm{mm}$ (from $2 \mathrm{~mm}$ ). This maneuver has been shown to reduce neurotransmitter release $\left(\mathrm{Mg}^{2+}\right.$ by blocking the $\mathrm{Ca}^{2+}$ channels and other nonspecific channels) (Martin, 1977; Hagiwara and Byerly, 1981; Lansman et al., 1986; Katz et al., 1997). Moreover, the probability of neurotransmitter release will be decreased, presumably because both resting $\mathrm{Ca}^{2+}$ levels and $\mathrm{Ca}^{2+}$ entry are reduced. Application of the above medium caused a significant reduction in the fEPSPs in the young animals (Fig. 7A, left, open bar, $B$ ). In seven young slices, the low $\mathrm{Ca}^{2+}$-high $\mathrm{Mg}^{2+}$ saline caused a $62 \pm 5 \%$ reduction of the fEPSP, compared with a reduction of only $31 \pm 7 \%$ in the aged slices $(p<0.01$; paired Student's $t$ test) (Fig. 7A, left, filled bar). The time required to cause the depression was $\sim 15-20$ min (Fig. $7 B$ ). Similar time was required to obtain complete reversal in the normal perfusate.

We next asked whether application of BAPTA-AM can cause a depression of the fEPSPs in the aged slices when calcium influx is reduced. Application of $1 \mu \mathrm{M}$ BAPTA-AM and $1 \mathrm{~mm}$ probenecid (in the above saline containing $0.5 \mathrm{mM} \mathrm{Ca}^{2+}$ and $4 \mathrm{~mm}$ $\left.\mathrm{Mg}^{2+}\right)$ depressed the fEPSP in the aged slices by $51 \pm 8 \%(n=$ 8 slices from 5 rats) (Fig. $7 A$, right, filled bar). Similar results were obtained when BAPTA-AM and the anion blocker probenecid were applied to the younger slices $(n=7$ slices from 4 rats; depression by $61 \pm 5.8 \%$ ) (Fig. $7 A$, right, open bar). Also shown in Figure $7 B$, bottom, is the time course for this effect in one aged slice. As can be seen from this figure, recovery from the BAPTAinduced synaptic inhibition in the presence of the above mentioned saline occurred after application of a $1 \mathrm{~Hz}$ repetitive stimulation for $16 \mathrm{sec}$ (Fig. 7B, bottom, arrows). After perfusion with normal ACSF, the amplitude of the fEPSP returned toward the control level.

If after perfusing with low $\mathrm{Ca}^{2+}$-high $\mathrm{Mg}^{2+}$ saline the aged slice takes on "younger" characteristics, the observed depressive effects of BAPTA-AM will not be mimicked by EGTA-AM, which has no effect on younger animals (Ouanounou et al., 1996b). If this hypothesis is correct, then it is very likely that elevated $\mathrm{Ca}^{2+}$ in aged animals might be caused by excessive $\mathrm{Ca}^{2+}$ influx. In a set of five experiments on aged slices, application of EGTA-AM in low $\mathrm{Ca}^{2+}$-high $\mathrm{Mg}^{2+}$ saline caused no significant change of the fEPSP amplitude $(n=5$ slices from 4 rats).

\section{The voltage-gated calcium channel blocker cobalt has different effects on slices from aged and young animals}

From the above results, it seemed that in this preparation aging could be associated with greater influx of $\mathrm{Ca}^{2+}$. Although there appears to be a number of potential sites for altered $\mathrm{Ca}^{2+}$ influx, some studies suggest enhanced voltage-gated $\mathrm{Ca}^{2+}$ influx (Campbell et al., 1996; Thibault and Landfield, 1996). Divalent metals, 


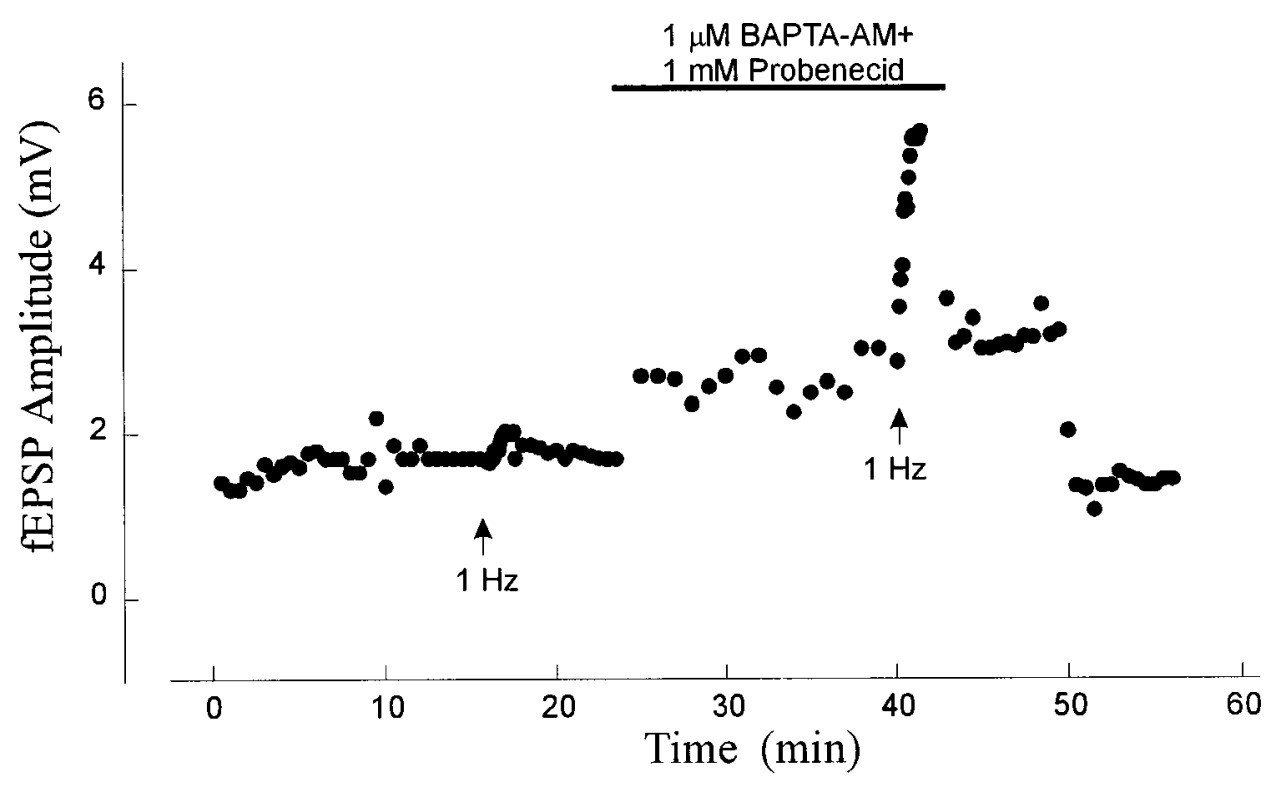

Figure 6. Repeated stimulation $(1 \mathrm{~Hz}$ for $16 \mathrm{sec}$ ) causes an increase in the fEPSP amplitude in the presence of BAPTA-AM in the aged slice. Repetitive stimulation before the application of $1 \mu \mathrm{M}$ BAPTA and $1 \mathrm{~mm}$ probenecid had no effect, but in the presence of BAPTA-AM, it caused a significant increase in the fEPSP amplitude. Arrows indicate the times at which $1 \mathrm{~Hz}$ stimulation for $16 \mathrm{sec}$ was applied. Similar results were obtained from eight slices. such as cobalt, have been used in neuropharmacological studies to block synaptic transmission presynaptically (Kretz, 1984; Kaneko and Tachibana, 1986; Dickie and Davies, 1992). In the present study, $0.7 \mathrm{~mm}$ cobalt application to young and aged slices revealed strikingly different results. In eight slices from young-mature rats, $0.7 \mathrm{~mm}$ cobalt depressed the fEPSPs by $43 \pm 2 \%$, but in seven slices from the aged rats, $0.7 \mathrm{mM}$ cobalt caused a $19 \pm 4 \%$ enhancement of the fEPSP (Fig. 8). Prolonging the incubation time of $0.7 \mathrm{mM} \mathrm{Co}^{2+}$ in the aged slices to $1 \mathrm{hr}$ produced the same result. We therefore decided to increase the concentration of $\mathrm{Co}^{2+}$ to $1.4 \mathrm{~mm}$, which depressed synaptic transmission in the aged slices by $\sim 45 \%$ (Fig. 8 ). The same concentration of cobalt $(1.4 \mathrm{~mm})$ depressed synaptic transmission in young slices by $78 \pm$ $2.3 \%$ ( $n=5$ slices from 5 rats) (Fig. 8). These results suggest significant modification of the number and function of the voltage-gated calcium channels during the process of normal aging.

Application of $1 \mu \mathrm{M}$ BAPTA-AM and $1 \mathrm{~mm}$ probenecid with $1.4 \mathrm{mM}$ cobalt in the aged slices caused a depression of $50 \pm 4 \%$ ( $n=7$ slices from 4 rats; data not shown), demonstrating, as before, that by blocking $\mathrm{Ca}^{2+}$ influx and thereby presumably lowering intracellular calcium, BAPTA "resumes" its role of depressing synaptic transmission as in the young slices.

\section{DISCUSSION}

The BAPTA-AM effects of enhancing fEPSPs in aged slices were striking, because BAPTA-AM attenuates synaptic transmission in various preparations (Charlton and Iwanchshyn, 1986; Adler et al., 1991; Niesen et al., 1991; Robitaille and Charlton, 1992; Robitaille et al., 1993a,b; Hunt et al., 1994; Tymianski et al., 1994b; Winslow et al., 1994; Blundon et al., 1995; Ouanounou et al., 1996b). Hippocampal synaptic physiology appears to be different in slices from aged compared with young animals in their response to $\mathrm{Ca}^{2+}$ chelators or to diminishing inward $\mathrm{Ca}^{2+}$ flux, supporting the hypothesis that aging results in a persistent increase in the free cytoplasmic calcium concentration (Verkhratsky and Toescu, 1998). These differential effects of calcium chelators cannot be caused by poor loading, because increasing the concentration and exposure time of BAPTA-AM produced similar results, and BAPTA-AM was able to reduce fEPSPs in aged slices once treatments to markedly reduce presynaptic $\mathrm{Ca}^{2+}$ influx were used.

\section{Calcium hypothesis of aging}

The calcium hypothesis of aging (for review, see Khachaturian, 1989, 1994; Disterhoft et al., 1993; Landfield, 1994; Verkhratsky and Toescu, 1998) suggests that basal intracellular calcium is increased in aged animals, altering $\mathrm{Ca}^{2+}$-dependent processes, such as neurotransmitter release, synaptic plasticity, and protease activity. In aged CA1 neurons, a direct mechanism for increasing intracellular calcium has been found; L-type $\mathrm{Ca}^{2+}$ channels (Thibault and Landfield, 1996) and currents (Campbell et al., 1996) are increased. In hippocampal dentate granule cells of aged rats, L-type $\mathrm{Ca}^{2+}$ currents were reduced, possibly because of an age-related increase in $\mathrm{Ca}^{2+}$-mediated inactivation of $\mathrm{Ca}^{2+}$ channels (Reynolds and Carlen, 1989). Furthermore, calcium currents were enhanced in the dentate neurons of aged, but not young, Fischer 344 rats by intracellular application of EGTA. By analogy to the effects on postsynaptic L-type currents, we hypothesize that buffering of presynaptic intracellular calcium is impaired in aged animals, leading to tonically raised calcium, which might impair rather than enhance synaptic function

\section{Calcium buffering and extrusion is impaired in aging}

Cytosolic calcium-binding (buffering) proteins are decreased in the hippocampus, but not the cerebellum or cortex, of aged rats (Villa, 1994; Papazafiri et al., 1995). The number of calbindinimmunoreactive neurons is decreased in the hippocampus of aged rats (Krzywkowski et al., 1995). Aged Fischer rats have lower $\mathrm{Ca}^{2+}$ extrusion through both the $\mathrm{Na} / \mathrm{Ca}^{2+}$ exchanger and the $\mathrm{Ca}^{2+}$ ATPase (Martinez-Serrano et al., 1992). Michaelis et al. (1984) found a decrease in the $V_{\max }$ of the $\mathrm{Ca}^{2+}$ ATPase and an increase in the $K_{\mathrm{m}}$ of the $\mathrm{Na} / \mathrm{Ca}^{2+}$ exchanger in synaptic membranes from 23- to 25-month-old rats compared with younger rats. The ameliorative effects of the addition of a membranepermeable calcium buffer may be attributable to enhanced calcium buffering. 

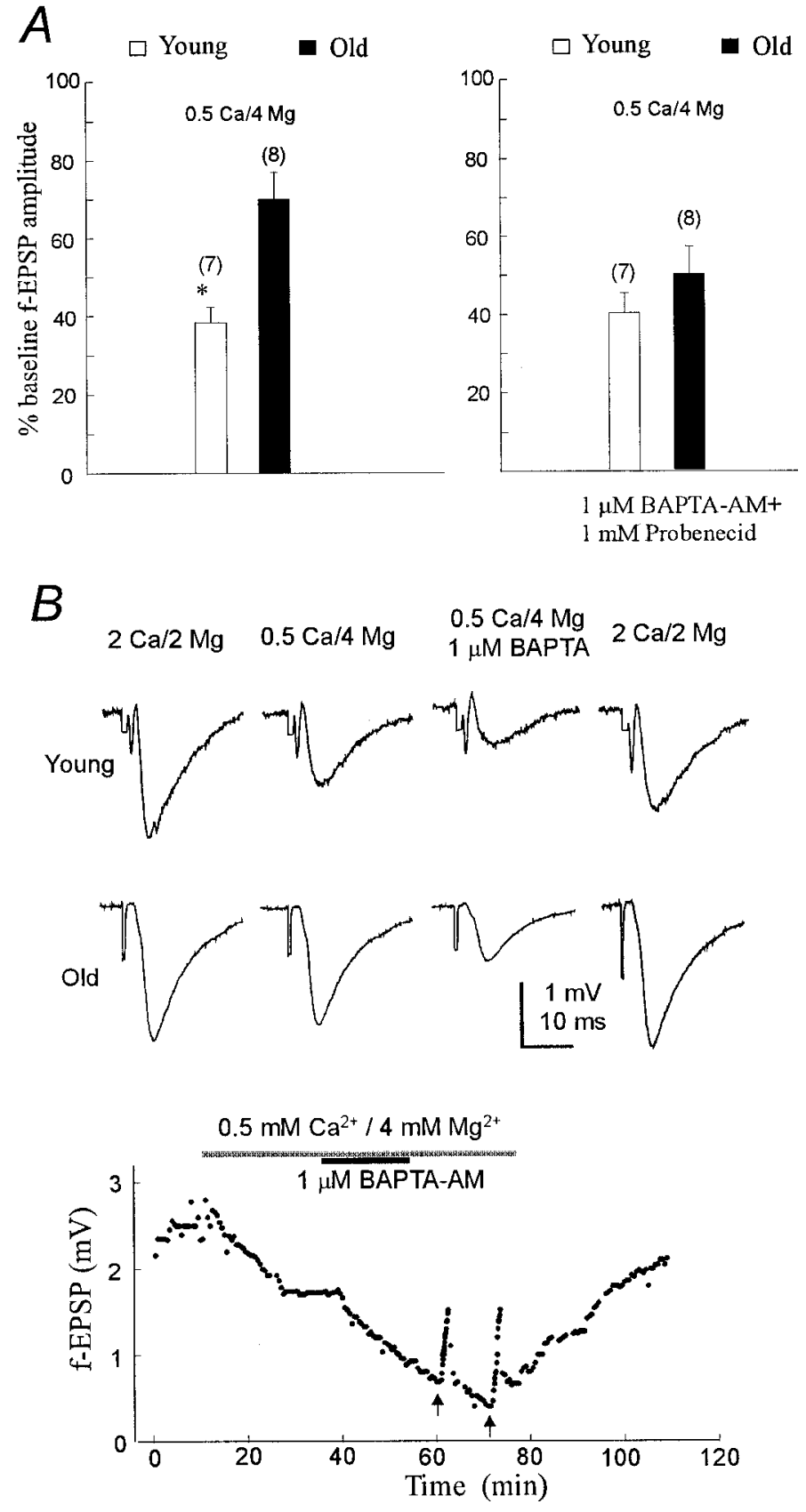

Figure 7. Effects of low $\mathrm{Ca}^{2+}$-high $\mathrm{Mg}^{2+}$ saline on the fEPSP amplitude in young and aged slices. $A$, Slices were perfused initially with normal ACSF and, after stable control responses were achieved, with $0.5 \mathrm{~mm}$ $\mathrm{Ca}^{2+}$ and $4 \mathrm{mM} \mathrm{Mg}^{2+}$ ACSF. Left, The percent of baseline fEPSP in the low $\mathrm{Ca}^{2+}$-high $\mathrm{Mg}^{2+}$ saline. Open bars represent the percent (mean \pm $\mathrm{SE}$ ) of the baseline response of the fEPSP amplitude when switching from the normal ACSF to the $0.5 \mathrm{mM} \mathrm{Ca}^{2+}-4 \mathrm{mM} \mathrm{Mg}^{2+} \mathrm{ACSF}$ in young slices, and filled bars represent those in old slices. Note that aged slices were less affected by the reduction of $\mathrm{Ca}^{2+}-\mathrm{Mg}^{2+}$ than young slices. ${ }^{*} p<0.01$; paired Student's $t$ test. Numbers in parentheses represent the number of slices used in each group. Right, Application of $1 \mu \mathrm{M}$ BAPTA-AM and 1 $\mathrm{mm}$ probenecid in the presence of low $\mathrm{Ca}^{2+}$-high $\mathrm{Mg}^{2+}$ causes further attenuation of the fEPSP in both the young and old slices. Slices were perfused as described above. After stability was achieved in the low $\mathrm{Ca}^{2+}$-high $\mathrm{Mg}^{2+}, 1 \mu \mathrm{M}$ BAPTA-AM and $1 \mathrm{~mm}$ probenecid were applied, causing a reduction of $\sim 40-50 \%$ in the fEPSP amplitude in the slices taken from both young and aged Fischer 344 rats (open bars, young; filled bars, old). B, Top, Sample fEPSP recordings from stratum radiatum. Bottom, Effect of low $\mathrm{Ca}^{2+}$-high $\mathrm{Mg}^{2+}$ saline and BAPTA-AM in one old slice. One micromolar probenecid was applied at the beginning of the

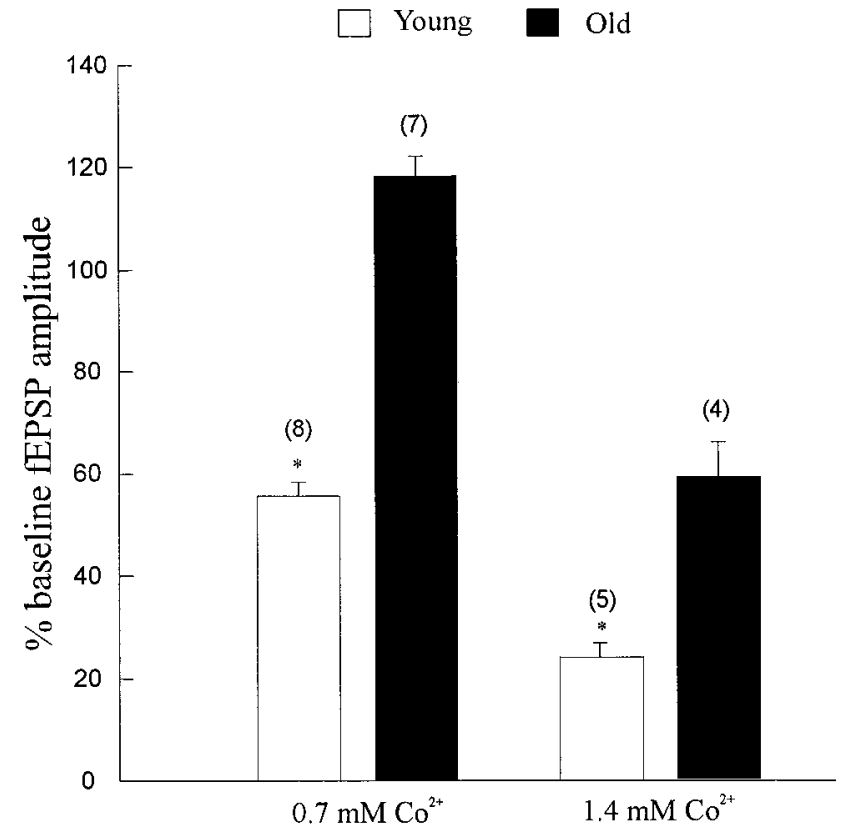

Figure 8 . The voltage-gated calcium channel blocker cobalt causes different effects on the fEPSP in young and aged slices. Slices were perfused with normal ACSF and later with ACSF containing $0.7 \mathrm{mM} \mathrm{Co}^{2+}$. Bars represent mean $\pm \mathrm{SE}$ change from baseline. As can be viewed, $0.7 \mathrm{~mm}$ $\mathrm{Co}^{2+}$ caused $\sim 45 \%$ reduction in the fEPSP amplitude in the young (open bars), whereas the same concentration of $\mathrm{Co}^{2+}$ caused $20 \%$ enhancement in the fEPSP amplitude (filled bars). Increasing the concentration of $\mathrm{Co}^{2+}$ to $1.4 \mathrm{~mm}$ caused remarkable attenuation of the fEPSP in young slices (open bars), and the reduction in aged was similar to the effect of 0.7 $\mathrm{mm}$ in young. Numbers in brackets indicate the number of slices in each group. * $p<0.01$; paired Student's $t$ test.

\section{$\mathrm{Ca}^{2+}$ binding kinetics of BAPTA compared with EGTA}

BAPTA has rapid $\mathrm{Ca}^{2+}$ binding kinetics compared with EGTA (Tsien, 1980; Neher, 1986). BAPTA can markedly attenuate neurotransmitter release in squid synaptic terminals (Adler et al., 1991), frog synaptic terminals (Robitaille and Charlton, 1992; Robitaille et al., 1993a), crayfish nerve terminals (Winslow et al., 1994), and in the Calyx of Held (Helmchen et al., 1997), presumably by shuttling calcium ions away from synaptic active zones where transmitter release is triggered. BAPTA-AM, but not EGTA-AM, attenuates excitatory neurotransmission in hippocampal slices, possibly by acting presynaptically (Niesen et al., 1991; Tymianski et al., 1994b; Ouanounou et al., 1996b). The kinetics of EGTA-calcium binding are slow relative to the initiation of transmitter release so that EGTA may be unable to reduce calcium concentration rapidly enough to reduce transmitter release in this preparation, although EGTA does affect release at crayfish neuromuscular junction (Winslow et al., 1994) and the Calyx of Held, as demonstrated by Helmchen et al.(1997). However, in our study, fEPSP enhancement was also achieved when the aged slices were perfused with EGTA-AM, an effect that we did not observe in the young slices (Fig. 4). This supports the notion that cytoplasmic calcium is elevated in aged neurons,

$$
\leftarrow
$$

experiment and was removed at the same time as the low $\mathrm{Ca}^{2+}$-high $\mathrm{Mg}^{2+}$ saline. Note that $1 \mathrm{~Hz}$ repetitive stimulation for $16 \mathrm{sec}$ (arrows) facilitated the fEPSP after BAPTA-AM application. In addition, after perfusion with normal ACSF, the amplitude of the fEPSP returned toward the control level. Similar results were obtained from eight slices. 
because fast association and dissociation calcium binding kinetics were not required here.

\section{Presynaptic or postsynaptic actions}

We hypothesize that the major effects of membrane-permeant calcium chelators on the fEPSPs could be on the presynaptic terminals, in part because of the overwhelming amount of evidence showing that alterations in presynaptic calcium effects neurotransmitter release. Loading the postsynaptic neuron with high concentrations of BAPTA did not alter the effects of BAPTA-AM on fEPSPs in the CA1 region in slices from youngmature rats (Velumian et al., 1998). In CA1 presynaptic terminals of aged animals, there is increased calcium that was decreased by preadministration of BAPTA-AM (Morris et al., 1998). However, we cannot exclude a postsynaptic action, because there are several studies showing that alterations in postsynaptic calciumdependent events can effect neurotransmission. An L-type calcium channel blocker enhanced hippocampal long-term potentiation in aged animals, an effect correlated with depression of the calcium-activated afterhyperpolarization measured postsynaptically (Norris et al., 1998). In CA1 neurons, increased postsynaptic calcium entry via voltage-sensitive calcium channels transiently potentiates EPSPs (Kullmann et al., 1992). Inhibition of postsynaptic calcineurin activity induced postsynaptic calciumdependent synaptic potentiation in adult CA1 neurons (Wang and Kelly, 1997).

\section{Frequency facilitation}

The increase in EPSP that occurs during or after repetitive activation has long been viewed as a possible substrate of behavioral or functional plasticity (Massicotte and Baudry, 1991; Muller et al., 1991). However, the mechanisms of central frequency facilitation remain unclear. The amount of frequency facilitation in the aged hippocampus responses is markedly reduced (Landfield and Lynch, 1977). The deficit appears to involve both presynaptic and postsynaptic components; moreover, alterations in postsynaptic membrane hyperpolarization may well contribute to impaired transmission, particularly during periods of high frequency activity (Pitler and Landfield, 1987; Landfield, 1994). In our experiments, aged slices exhibited significantly less frequency facilitation than young-mature ones, which markedly improved after application of BAPTA-AM (or EGTA-AM) to the aged slices. Because frequency facilitation itself is $\mathrm{Ca}^{2+}$-dependent, it appears paradoxical that excess $\mathrm{Ca}^{2+}$ can reduce frequency facilitation. However, elevated calcium might impair frequency facilitation of the fEPSP by $\mathrm{Ca}^{2+}$-dependent inactivation of subsequent $\mathrm{Ca}^{2+}$ influx (Landfield et al., 1986) or by increased $\mathrm{Ca}^{2+}$-dependent hyperpolarization of the axon terminals or dendrites, resulting in presynaptic action potential failure or a "shunt" of the dendritic EPSP (Landfield, 1994). Frequency facilitation is usually greater at lower quantal content. Therefore, lowering extracellular $\mathrm{Ca}^{2+}$ or applying BAPTA, both of which lower quantal content, might increase facilitation. Although the ratio of the first to second fEPSP (paired-pulse facilitation) and the quantal content may not change with aging (Landfield and Lynch, 1977; Barnes et al., 1992; Deupree et al., 1993), the facilitation that we measured was over a period of 16 stimuli at 1 Hz. With BAPTA-AM, the absolute size of the fEPSPs grew markedly during the 16 stimuli, whereas the ratio of the first two fEPSPs could remain constant. Further experiments are required to properly investigate these phenomena. $\mathrm{A} \mathrm{Ca}^{2+}$ receptor for facilitation could be saturated in old neurons (Stanley, 1986;
Yamanda and Zucker, 1992). Reducing $\left[\mathrm{Ca}^{2+}\right]_{\mathrm{i}}$ may unsaturate the facilitation $\mathrm{Ca}^{2+}$ receptor so that it can function again. In aged neurons, a chronic $\mathrm{Ca}^{2+}$ leak may elevate $\left[\mathrm{Ca}^{2+}\right]_{i}$. Thus, application of BAPTA is less effective, because it becomes saturated with $\mathrm{Ca}^{2+}$. BAPTA may reduce presynaptic $\left[\mathrm{Ca}^{2+}\right]_{\mathrm{i}}$, thus reducing spontaneous release and making more vesicles available for evoked release. BAPTA may also reduce activation of $K_{\mathrm{Ca}}$ channels, making the presynaptic action potential longer, thereby admitting more $\mathrm{Ca}^{2+}$, causing increased neurotransmitter release (Robitaille and Charlton, 1992; Robitaille et al., 1993a,b).

\section{Reducing calcium influx reverses "aging" effects}

High $\mathrm{Ca}^{2+}$ might impair frequency potentiation by saturation of binding sites for release or by rapid transmitter depletion (Landfield, 1994). Because $\mathrm{Mg}^{2+}$ competitively inhibits these calcium actions, the beneficial effects of $\mathrm{Mg}^{2+}$ on hippocampal synaptic potentiation in aged rats suggests that calcium may be elevated in these cells. Magnesium facilitates maze reversal learning and improves hippocampal frequency facilitation in aged rats (Landfield and Morgan, 1984). Blocking calcium influx by decreasing the $\mathrm{Ca}^{2+} / \mathrm{Mg}^{2+}$ ratio improved intracellular and extracellular measures of frequency facilitation in aged hippocampal slices (Landfield et al., 1986). We showed that low $\mathrm{Ca}^{2+}$-high $\mathrm{Mg}^{2+}$ caused a reversal of the effect of the BAPTA-AM (but not that of EGTA-AM) in aged slices, here showing synaptic transmission resembling that of young slices. These data suggest that reducing calcium influx can reverse some of the functional effects of aging. Also, in younger slices, $0.7 \mathrm{~mm} \mathrm{Co}^{2+}$ attenuated fEPSPs by $\sim 50 \%$, whereas in aged slices, it enhanced fEPSPs by $20 \%$. Only after doubling the $\mathrm{Co}^{2+}$ concentration to $1.4 \mathrm{~mm}$ were similar results obtained in the aged slices, i.e., $\sim 50 \%$ depression of the fEPSP (Fig. 8). Recently, we showed that the volatile anesthetic isoflurane depressed fEPSPs significantly more in aged than in young slices (Ouanounou et al., 1998a). However, when the slices were exposed to low $\mathrm{Ca}^{2+}$-high $\mathrm{Mg}^{2+}$ or to cobalt (Ouanounou et al., 1998b), the isoflurane depression was similar in young and old slices. Overall, these results in old neurons suggest $\mathrm{Ca}^{2+}$ dependent modifications in the number of presynaptic $\mathrm{Ca}^{2+}$ channels, the number of postsynaptic receptors, or altered function of these channels, possibly from increased cytoplasmic calcium.

\section{Calcium-mediated cellular dysfunction}

Thus, neuronal dysfunction in aging could be attributable to the buildup of intracellular $\mathrm{Ca}^{2+}$ via NMDA receptors, voltagegated $\mathrm{Ca}^{2+}$ channels, impaired membrane pumps or exchangers, leakage from intracellular stores, and/or by impaired intracellular $\mathrm{Ca}^{2+}$ buffering. Increased free cytosolic $\mathrm{Ca}^{2+}$ could then activate several $\mathrm{Ca}^{2+}$-dependent processes, leading to neuronal damage.

\section{REFERENCES}

Adler EM, Augustine GJ, Duffy SN, Charlton MP (1991) Alien intracellular calcium chelator attenuate neurotransmitter release at the squid giant synapse. J Neurosci 11:1469-1477.

Augustine GJ, Charlton MP, Smith SJ (1985) Calcium entry and transmitter release at voltage-clamped terminals of squid. J Physiol (Lond) 367:163-181.

Augustine GJ, Adler EM, Charlton MP (1991) The calcium signal for transmitter secretion from presynaptic nerve terminals. Ann NY Acad Sci 636:365-381.

Barnes CA (1994) Normal aging: regionally specific changes in hippocampal synaptic transmission. Trends Neurosci 17:13-18.

Barnes CA, Rao G, Foster TC, McNaughton BL (1992) Region-specific age effects on AMPA sensitivity: electrophysiological evidence for loss 
of synaptic contacts in hippocampal CA1 field. Hippocampus 2:457-468

Blaustein MP (1988) Calcium transport and buffering in neurons. Trends Neurosci 11:438-443.

Bliss TVP, Collingridge GL (1993) A synaptic model of memory: long term potentiation in the hippocampus. Nature 361:31-39.

Blundon JA, Wright SN, Brodwick MS, Bittner GD (1995) Presynaptic calcium activated potassium channels and calcium channels at a crayfish neuromuscular junction. J Neurophysiol 73:178-189.

Campbell LW, Su-Yang H, Thibault O, Blalock EM, Landfield PW (1996) Aging changes in voltage-gated calcium currents in hippocampal CA1 neurons. J Neurosci 16:6286-6295.

Charlton MP, Iwanchshyn G (1986) Exogenous calcium buffer reduces synaptic transmitter release and facilitation. Soc Neurosci Abstr 12:817.

Choi DW (1988) Calcium-mediated neurotoxicity: relationship to specific channel types and role in ischemic damage. Trends Neurosci 11:465-467.

Choi DW (1995) Calcium: still centre in hypoxic-ischemic neuronal death. Trends Neurosci 18:58-60.

Deupree DL, Bradley J, Turner DA (1993) Age-related alterations in potentiation in CA1 region in F344 rats. Neurobiol Aging 14:249-258.

Dickie BGM, Davies JA (1992) Calcium channel blocking agents and potassium-stimulated release of glutamate from cerebellar slices. Eur J Pharmacol 229:97-99.

Disterhoft JF, Moyer JR, Thompson LT, Kowaslka M (1993) Functional aspects of calcium channel modulation. Clin Neuropharmacol 16:S12-S24.

Ghosh A, Greenberg ME (1995) Calcium signalling in neurons: molecular mechanisms and cellular consequences. Science 268:239-247.

Gibson GE, Peterson C (1987) Calcium and the aging nervous system. Neurobiol Aging 8:329-344.

Hagiwara S, Byerly L (1981) Calcium channel. Annu Rev Neurosci 4:69-125.

Helmchen F, Borst JG, Sakman B (1997) Calcium dynamics associated with a single action potential in a CNS presynaptic terminal. Biophys $\mathrm{J}$ 72:1458-1471

Hunt JM, Redman RS, Silinsky EM (1994) Reduction by intracellular calcium chelation of acetylcholine secretion without occluding the effects of adenosine at frog motor nerve endings. Br J Pharmacol 111:753-758.

Iacopino AM, Christakos S (1990) Specific reduction of calcium binding protein (28-kilodalton calbindin-D) gene expression in aging and neurodegenerative disease. Proc Natl Acad Sci USA 87:4078-4082.

Kaneko A, Tachibana M (1986) Blocking effects of cobalt and related ions on the $\gamma$-aminobutyric acid-induced current in turtle retinal cones. J Physiol (Lond) 373:463-479.

Kao JP, Tsien RY (1988) $\mathrm{Ca}^{2+}$ binding kinetics of Fura-2 and Azo-1 from temperature-jump relaxation measurements. Biophys $\mathrm{J}$ 53:635-639.

Katz E, Protte DA, Ferro PA, Rosato MD, Uchitel OD (1997) Effects of $\mathrm{Ca}^{2+}$ channel blocker neurotoxins on transmitter release and presynaptic currents at the mouse neuromuscular junction. Br J Pharmacol 121:1531-1540.

Khachaturian ZC (1989) The role of calcium regulation in brain aging: reexamination of a hypothesis. Aging 1:17-34.

Khachaturian ZC (1994) Calcium hypothesis of Alzheimer's disease and brain aging. Ann NY Acad Sci 747:1-11.

Kretz R (1984) Local cobalt injection: a method to discriminate presynaptic axonal from postsynaptic neuronal activity. J Neurosci Methods 11:129-135.

Krzywkowski P, Debilbao F, Senut MC, Lamour Y (1995) Age-related changes in Parvalbumin-immunoreactive and GABA-immunoreactive cells in the rat septum. Neurobiol Aging 16:29-40.

Kudo Y, Takeda K, Yamazaki K (1990) Quin2 protects against neuronal cell death due to $\mathrm{Ca}^{2+}$ overload. Brain Res 528:48-54.

Kullmann DM, Perkel DJ, Manabe T, Nicoll RA (1992) $\mathrm{Ca}^{2+}$ entry via postsynaptic voltage-sensitive $\mathrm{Ca}^{2+}$ channels can transiently potentiate excitatory synaptic transmission in the hippocampus. J Neurosci 9:1175-1183.

Landfield PW (1994) Increased hippocampal $\mathrm{Ca}^{2+}$ channel activity in brain aging and dementia. Ann NY Acad Sci 747:351-364.

Landfield PW, Lynch GS (1977) Impaired monosynaptic potentiation in vitro hippocampal slices from aged, memory-deficient rats. J Gerontol 32:523-533.

Landfield PW, Morgan G (1984) Chronically elevating plasma $\mathrm{Mg}^{2+}$ improves hippocampal frequency potentiation and reversal learning in aged and young rats. Brain Res 322:167-171.

Landfield PW, Pitler TA (1984) Prolonged $\mathrm{Ca}^{2+}$-dependent afterhyperpolarization in hippocampal neurons of aged rats. Science 226:1089-1092.

Landfield PW, Pitler TA, Applegate MD (1986) The effects of high Mg ${ }^{2+}$ to $\mathrm{Ca}^{2+}$ ratios on frequency potentiation in hippocampal slices of young and aged rats. J Neurophysiol 56:797-811.

Lansman JB, Hess P, Tsien RW (1986) Blockade of current through single calcium channels by $\mathrm{Cd}^{2+}, \mathrm{Mg}^{2+}$ and $\mathrm{Ca}^{2+}$ voltage and concentration dependence of calcium entry into the pore. J Gen Physiol 88:321-347.

Martin AR (1977) Junctional transmission. II. Presynaptic mechanisms. In: Handbook of physiology. The nervous system, Chap 10, pp 329-355. Bethesda, MD: American Physiology Society.

Martinez A, Vitorica J, Bogonez E, Satrustegui J (1987) Differential effects of age on the pathways of calcium influx into nerve terminals. Brain Res 435:249-257.

Martinez-Serrano A, Blanco P, Satrustegui J (1992) Calcium binding to the cytosol and calcium extrusion mechanisms in intact synaptosomes and their alterations with aging. J Biol Chem 267:4673-4679.

Massicotte G, Baudry M (1991) Triggers and substrates of hippocampal synaptic plasticity. Neurosci Biobehav Rev 15:415-423.

Michaelis ML, Johe K, Kitos TE (1984) Age-dependent alterations in synaptic membrane systems for calcium regulation. Mech Ageing Dev 25:215-225.

Morris ME, Carlen P, Jahromi SS, Pivneva TA (1998) Ultrastructural $\mathrm{Ca}^{2+}$ stores during aging: modulation by BAPTA. Soc Neurosci Abstr 24:1973.

Muller D, Buchs PA, Stoppini L, Boddeke H (1991) Long term potentiation, protein kinase $\mathrm{C}$, and glutamate receptors. Mol Neurobiol 5:277-288.

Neher E (1986) Concentration profiles of intracellular calcium in the presence of a diffusible chelator. In: Calcium electrogenesis and neuronal functioning (Klee M, Neher E, eds), pp 80-96. Berlin: Springer-Verlag.

Nicoll RA, Malenka RC (1995) Contrasting properties of two forms of long-term potentiation in the hippocampus. Nature 377:115-118.

Niesen C, Charlton MP, Carlen PL (1991) Postsynaptic and presynaptic effects of the calcium chelator BAPTA on synaptic transmission in rat hippocampal dentate granule neurons. Brain Res 555:319-325.

Norris CM, Halpain S, Foster TC (1998) Reversal of aged-related alterations in synaptic plasticity and blockade of L-type $\mathrm{Ca}^{2+}$ channels. J Neurosci 18:3171-3179.

Ouanounou A, Zhang L, Charlton MP, Carlen PL (1996a) Excitatory synaptic transmission is enhanced in aged hippocampal neurons by calcium chelator. FASEB J [Abstr] 10:3914.

Ouanounou A, Zhang L, Tymianski M, Charlton MP, Wallace CM, Carlen PL (1996b) Accumulation and extrusion of permeant $\mathrm{Ca}^{2+}$ chelator in attenuation of synaptic transmission at hippocampal CA1 neurons. Neuroscience 75:99-109.

Ouanounou A, El-Beheiry H, Carlen PL (1998a) Enhanced isoflurane suppression of excitatory synaptic transmission in the aged rat hippocampus. Br J Pharmacol [Abstr] 124:1075-1083.

Ouanounou A, El-Beheiry H, Carlen PL (1998b) Suppression of calcium influx reverses anaesthetic actions in old neurons. J Dent Res 77:143.

Papazafiri P, Podini P, Meldolesi J, Yamaguchi T (1995) Aging affects cytosolic $\mathrm{Ca}^{2+}$ binding-proteins and synaptic markers in the retina but not in cerebral cortex neurons of the rat. Neurosci Lett 186:65-68.

Pethig RR, Kuhn M, Payne R, Adler EM, Chen TH, Jaffe JH (1989) On the dissociation constants of BAPTA-AM type calcium buffers. Cell Calcium 10:491-498.

Pitler TA, Landfield PW (1987) Probable calcium-mediated inactivation in $\mathrm{Ca}^{2+}$ currents in mammalian brain neurons. Brain Res 410:147-153.

Reynolds JN, Carlen PL (1989) Diminished calcium currents in aged hippocampal dentate gyrus granule neurones. Brain Res 479:384-390.

Robitaille R, Charlton MP (1992) Presynaptic calcium signals and transmitter release are modulated by calcium activated potassium channels. J Neurosci 12:297-305.

Robitaille R, Adler EM, Charlton MP (1993a) Calcium and calcium gated potassium channels at the frog neuromuscular junction. J Physiol (Paris) 87:15-24.

Robitaille R, Garcia ML, Kaczorowski GJ, Charlton MP (1993b) Functional colocalization of calcium and calcium-gated potassium channels in control of transmitter release. Neuron 11:645-655. 
Scharfman HE, Schwartzkroin PA (1989) Protection of dentate hilar cells from prolonged stimulation by intracellular calcium chelation. Science 246:257-260.

Simpson PB, Challiss RAJ, Nahorski SR (1995) Neuronal $\mathrm{Ca}^{2+}$ stores: activation and function. Trends Neurosci 18:299-306.

Smith DO (1988) Muscle-specific decrease in presynaptic calcium dependence and clearance during and neuromuscular transmission in aged rats. J Neurophysiol 59:1069-1082.

Smith PD, Liesegang GW, Berger RL, Czerlinski G, Podolsky RJ (1984) A stopped-flow investigation of calcium ion binding by ethylene glycol bis $\left(\beta\right.$-aminoethyl ether)- $N, N^{\prime}$-tetraacetic acid. Anal Biochem 143:188195.

Stanley EF (1986) Decline in calcium cooperativity as the basis of facilitation at the squid giant synapse. J Neurosci 6:782-789.

Thibault O, Landfield PW (1996) Increase in single L-type calcium channels in hippocampal neurons during aging. Science 272:1017-1020.

Tsien RY (1980) New calcium indicators and buffers with high selectivity against $\mathrm{Mg}$ and protons: design, synthesis, and prototype structures. Biochemistry 19:2396-2404.

Tymianski M, Wallace MC, Spigelman I, Uno M, Carlen PL, Tator CH, Charlton MP (1993) Cell permeant $\mathrm{Ca}^{2+}$ chelators reduce early exitotoxic and ischemic neuronal damage in vitro and in vivo. Neuron 11:221-235.

Tymianski M, Charlton MP, Carlen PL, Tator CH (1994a) Properties of neuroprotective cell permeant $\mathrm{Ca}^{2+}$ chelator: effects on $\left[\mathrm{Ca}^{2+}\right]_{\mathrm{i}}$ and glutamate neurotoxicity in vitro. J Neurophysiol 72:1973-1991.

Tymianski M, Spigelman I, Zhang L, Carlen PL, Tator CH, Charlton MP, Wallace WC (1994b) Mechanism of action and persistence of neuroprotection by cell permeant $\mathrm{Ca}^{2+}$ chelator. J Cereb Blood Flow Metab 35:1-13.

Velumian AA, Ouanounou A, Carlen PL (1998) The site of action of BAPTA-AM on synaptic transmission in rat hippocampus is presynaptic. Soc Neurosci Abstr 24:568.

Verkhratsky A, Toescu EC (1998) Calcium and neuronal ageing. Trends Neurosci 21:2-7.

Villa A, Podini P, Panzeri MC, Raccheti G, Meldolesi J (1994) Cytosolic $\mathrm{Ca}^{2+}$ binding proteins during rat brain aging loss of calbindin and calretinin in the hippocampus, with no change in the cerebellum. Eur J Neurosci 6:1491-1499.

Wang JH, Kelly PT (1997) Postsynaptic calcineurin activity downregulates synaptic transmission by weakening intracellular $\mathrm{Ca}^{2+}$ signaling mechanisms in hippocampal CA1 neurons. J Neurosci 17:4600-4611.

Winslow JL, Duffy SN, Charlton MP (1994) Homosynaptic facilitation of transmitter release in crayfish is not affected by mobile calcium chelator implications for the residual ionized calcium hypothesis from electrophysiological and computational analyses. J Neurophysiol 72:1769-1793.

Yamanda WM, Zucker RS (1992) Time course of transmitter release calculated from simulations of a calcium diffusion model. Biophys $\mathbf{J}$ 61:671-682. 